\title{
Real and ideal European maritime transfers along the Atlantic coast during the Neolithic
}

\author{
Serge Cassen ${ }^{1}$, Carlos Rodríguez-Rellán ${ }^{2}$, Ramon Fábregas Valcarce ${ }^{3}$, \\ Valentin Grimaud 4, Yvan Pailler ${ }^{5}$, and Bettina Schulz Paulsson 6 \\ 1 CNRS, Laboratoire de recherche Archéologie et Architectures (umr6566), Université de Nantes, Nantes, FR \\ serge.cassen@univ-nantes.fr \\ 2 Departamento de Historia, Universidade de Santiago de Compostela, Praza da Universidade, Santiago de \\ Compostela, ES \\ carlos.rellan@usc.es \\ 3 Departamento de Historia. Universidade de Santiago de Compostela, Praza da Universidade, Santiago de \\ Compostela, ES \\ ramon.fabregas@usc.es \\ 4 Laboratoire de recherche Archéologie et Architectures, Université de Nantes, Nantes, FR \\ valentin.grimaud@univ-nantes.fr \\ 5 INRAP Grand Ouest (umr8215), Institut Universitaire Européen de la Mer, Plouzané, FR \\ yvan.pailler@inrap.fr \\ 6 Institutionen för historiska studier/arkeologi, Göteborgs universitet, Göteborg, SE \\ bettina.schulz.paulsson@gu.se
}

\begin{abstract}
The history of research on the Neolithic of the Atlantic façade shows how speculation about prehistoric mobility, especially across the sea, is mainly based on three types of archaeological evidence: megalithic monuments, rare stones, and pottery decoration. With the aim of approaching the issue from other perspectives, we have focused on the Morbihan area, a focal point of the European Neolithic during the mid-5th millennium BC. The analysis of this area has allowed us to grasp which objects, ideas and beliefs may have been desired, adopted and imitated at the time. We shall begin with an architectural concept, the standing stone. These were sometimes engraved with signs that can be directly compared between Brittany, Galicia (NW Spain) and Portugal, but for which there are no intermediate parallels in other areas of the French or Spanish coast. The unique accumulation and transformation of polished blades made of Alpine rocks and found inside tombs or in other sort of depositions in the Carnac region allowed us to establish a second link with Galicia and the Atlantic coast of the Iberian Peninsula, where certain types of the axes were imitated using a set of different rocks (sillimanite, amphibolite). Finally, the variscites and turquoises from different Spanish regions were used for the manufacture of beads and pendants at the Carnacean tombs, without it being possible - once again - to retrieve similar objects in the intermediate areas. The mastery of direct Atlantic sea routes is posed as an explanation for this geographical distribution. But, beyond the information drawn from specific artefacts - whose presence/absence should not be used in excess as an argument to endorse or underrate such movements across the ocean - we will return to a more poetic and universal phenomenon: the spell of the sea. Therefore, we will focus on the depictions of boats on the stelae of Morbihan to open such a debate.
\end{abstract}

KEY WORDS - Neolithic; maritime transfers; jade; Callaï; symbolic representations 


\title{
Resničen in idealen evropski morski transfer ob Atlantski obali v neolitiku
}

\begin{abstract}
IZVLEČEK - Zgodovina raziskav obdobja neolitika ob Atlantski obali kaže na to, da so domneve o premikih ljudi v prazgodovini, predvsem premiki po morju, osnovani predvsem na treh vrstah arheoloških podatkov: na megalitskih spomenikih, na redkih kamninah in na okrasu na lončenini. $V$ članku se bomo te teme lotili iz drugega vidika, in sicer se bomo osredotočili na območje departmaja Morbihan, ki je bil v središču dogajanja v evropskem neolitiku v sredini 5. tisočletja pr. $n$. št. Z analizo tega območja lažje razumemo, katere objekte, ideje in verovanja so $v$ tem obdobju ljudje najbolj pogosto želeli, posvojili in posnemali. Začeli bomo z arhitekturnim konceptom, menhirji/stoječimi kamni. Takšni kamni imajo občasno gravure z znaki, ki jih lahko neposredno vežemo na območje Bretanje, Galicije (SZ Španija) in Portugalske, medtem ko nimajo primerjav v vmesnih območjih ob francoski in španski obali. Enkraten zbir in preoblikovanje glajenih rezil, izdelanih na kamninah iz Alp, ki so bila odkrita v grobnicah ali drugih depozicijah na območju Carnaca, predstavlja drugo povezavo z območjem Galicije in Atlantsko obalo na Iberskem polotoku, kjer so bili najdeni posnetki nekaterih tipov sekir, izdelani iz različnih kamnin (silimanit, amfibolit). Tudi jagode in obeski, najdeni $v$ grobnicah $v$ Carnacu $v$ Bretanju, so bili izdelani iz mineralov variscita in turkiza, ki izvirata iz španskih regij, medtem ko takšni predmeti - ponovno - na vmesnih območjih niso bili odkriti. Takšna geografska porazdelitev se razlaga z obvladovanjem neposrednih morskih poti po Atlantiku v prazgodovini. Kljub informacijam, ki jih dobimo s takšnimi posebnimi najdbami - katerih prisotnost/odsotnost naj ne bi preveč pogosto uporabljali kot argument v podporo ali podcenjevanje takšnih premikov po oceanu - se bomo vrnili na bolj poetičen in univerzalen fenomen: čarobnost morja. Pri tem se bomo osredotočili in razpravljali predvsem na upodobitve ladij na stelah, najdenih na območju departmaja Morbihan.
\end{abstract}

KLJUČNE BESEDE - neolitik; morski transfer; žad; Callaï; simbolne upodobitve

\section{Foreword. A comparison.}

In order to properly deal with the request made by the organizers of a recent seminar in Sweden (Göteborg, June 8-10, 2018), namely, the issue of long distance contacts along the Atlantic façade of Europe in the second half of the $5^{\text {th }}$ millennium $\mathrm{BC}$, a simple comparison of objects, materials and representations was conducted based on three types of data:

- First, on the circulation of rare materials, such as specific rocks with an Iberian origin (variscite/turquoise, probably sillimanite) used for the manufacture of tools and ornaments, in parallel with the phenomenon of the terrestrial distribution of axes and rings made of Alpine rocks;

- Second, through the analysis of ceramic production, technical features and specific decoration patterns, seemingly shared between distant areas;

- Third, based on a specific type of architectural structure (the standing stone) and of different signs engraved on its surface, whose shared characteristics in different European lands cannot be easily conceived without a direct relationship.
Such a comparative exercise, and the role attributed to the ocean, connects with a tradition of research that goes back to the first descriptions of the megalithic monuments of Brittany. Thus, in the year 1760, the Comte de Caylus concluded - while observing the distribution of the Breton megaliths along the sea coast - that they had their origin in people coming by boat from Northern Europe through coastal journeys. Later, Joseph Déchelette (1908.626) evoked 'unnamed seafarers' to explain both the Atlantic diffusion of megaliths and that of the Neolithic idols coming from the Mediterranean through the Gadès pass. This author was followed - among others - by Thomas William Mansell De Guérin (1920), who interpreted the settlement of the Channel Islands as the result of diffusion of people from South Brittany, as seen in the related ceramics, jadeite and fibrolite axes, together with the worship of a female divinity. This was before Daryll Forde suggested, in 1930, the existence of these terrestrial and maritime movements - especially from Galicia and Portugal - based on the megaliths in 'tholos', the 'callais' and the axes made of 'green rocks' (Fig. 1). Less boldly, Vere Gordon Childe (1942) and Glyn Daniel (1941) consid- 
ered that Carnac and Spain were connected only through inland routes, while traveling by sea across the Mediterranean posed no conceptual problems for these authors.

Our exercise will, therefore, be conducted on part of the Atlantic coast of Europe. Since this synthesis will be anchored in the $5^{\text {th }}$ millennium BC, the references will not focus on Ireland, Scotland, England and Wales (for such possibilities from northern France, see Sheridan, Pailler 2011). The starting point will be the Carnac area, in the southern coast of Brittany, a region chosen due to its complexity, since it was the most dynamic centre in Western France for several centuries. A node that, regardless of the quantitative and qualitative scale of our observation, can only be defined as truly exceptional. The data, as we will see, cannot be interpreted without considering the hypothesis of maritime movements, and the control of such routes as a source of wealth. This possibility of seafaring over long distances will ultimately be tested by accounting for the power of the imaginary carried by the Ocean.

\section{objects-signs, weapons and adornments}

Considering yet again the sites of Morbihan that provided particularly unique objects, these are located in a quite small geographical area, barely $100 \mathrm{~km}^{2}$ around the protected bay of Quiberon, the real Morbihan (in Breton: the 'small sea').

\section{The Carnacean tumuli}

There are, in this region of Western France, more than one hundred earthen mounds (circular or elongated) containing individual (e.g., Bovelann 2) or multiple burials (e.g., Mané Lud central) dug into pits or arranged in stone or wood cists. The dimensions of these mounds vary between $5 \mathrm{~m}$ in diameter and $180 \mathrm{~m}$ long, and a maximum height (currently) ranging from $50 \mathrm{~cm}$ to $3 \mathrm{~m}$. Among such monuments, three stand out for their isolation in the landscape, gigantic proportions and for the quantity and quality of the objects made of jade and callais they contained. These funerary spaces have no structured access and preserved the remains of only one individual. The volumes of their tumuli are extraordinary: Saint-Michel in Carnac $\left(35000 \mathrm{~m}^{3}\right)$, Tumiac in Arzon $\left(16000 \mathrm{~m}^{3}\right)$ and Mané er Hroëck in Locmariaquer $\left(14600 \mathrm{~m}^{3}\right)$; while their maximum height rises between 10 and $15 \mathrm{~m}$ above the ground (Cassen et al. 2011). The current state of knowledge suggests Mané er Hroëck was the oldest of the three, followed by Tumiac and - finally - Saint-Michel. The last two have radiocarbon dates available (about $4500 \mathrm{cal}$ $\mathrm{BC}$ ), obtained from diverse samples and by different researchers (Cassen et al. 2012; 2019; Pétrequin et al. 2012a; Schulz Paulsson et al. 2019).

\section{Jade polished blades and their imitations}

At the origin of the term 'Neolithic', enunciated by John Lubbock in 1865 , the jade polished blades of Morbihan were the objects used to illustrate the con-

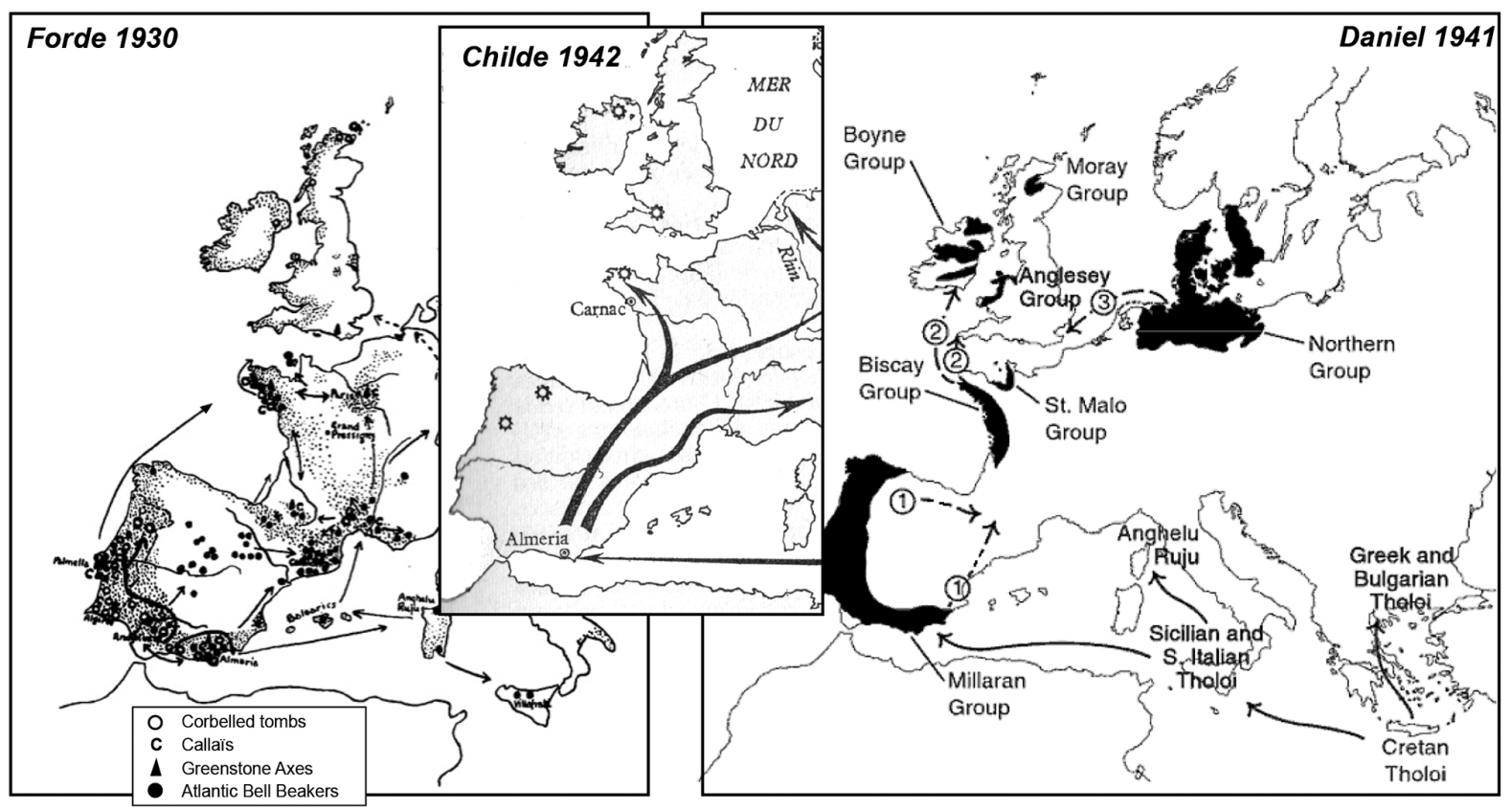

Fig. 1. Terrestrial and maritime diffusion of megalithic tombs, 'green stone' axes and 'callaï', after Forde 1930; terrestrial diffusion of megaliths and metallurgy after Childe 1942 (French edition 1961), and after Daniel 1941 (CAD by S. Cassen). 
cept of 'new stone', specifically those of the Largueven hoard and the tumulus of Tumiac, discovered in 1808 and 1853 . The recent study of such magnificent objects has shown that the geological origin of the rocks used for making them (jadeitite, eclogite, omphacitite) was mainly located on the Italian side of the Alps. Their distribution is widespread across Western Europe, with extensions towards the Black Sea and another dynamic focus existing at the time, centred on Varna (Bulgaria) (Pétrequin et al. 2012c). A maritime 'trade' is the obvious explanation for the transfer of these polished blades from the continent to the British Isles (Piggott 1953), while river navigation probably sped their dissemination on the mainland (Camps 1970).

In order to illustrate this phenomenon, both in its deep insertion in the material culture of the Carnac region and in its impact at a European scale, we shall turn to a very specific type of axe found both in the Carnacean tumuli and in the local contemporary hoards: the butt-perforated Tumiac type. This is a Morbihan invention, a local transformation - by repolishing - of a ground blade transferred from the Alpine regions. One of these Tumiac axes has been found in the Iberian Peninsula, in Vilapedre, Galicia (NW Spain) (Fig. 2; Fábregas et al. 2012). It is an object clearly made of jadeitite that travelled from Brittany after its repolishing (being, therefore, a secondary transfer). Most interestingly, there are no known intermediate finds along the northern coast of Spain.

The Tumiac axes were reproduced, in their general lines, in northwestern Spain and Portugal, resulting in the so-called Cangas type axes (Fig. 2). The Cangas are triangular, very elongated and occasionally fusiform axes; as in the original model, their butt is always perforated. The raw materials used were mainly sillimanite and amphibolite (Pétrequin et al. 2012b). Their manufacture and dissemination dates back to the transition between the $5^{\text {th }}$ and $4^{\text {th }}$ millennia $\mathrm{BC}$. This phenomenon of imitation is also visible in other areas of Europe, as in the case of the Zug blades, mainly made of ser- pentinite, whose presence underlines the penetrating force of the objects-symbols from Morbihan in areas such as Switzerland.

Surprisingly, we have identified a typical Cangas axe in Brittany that deserves further investigation after its original publication (Le Guern 2011). Found in Rest Louët, south of the town of Plévin (Finistère) in the 1980s, its raw material was initially identified as fibrolite, probably due to its fibrous appearance (Fig. 3). Revisited in 2014 by one of the current authors (YP), nephrite was considered the most probable raw material. This new examination allowed us to verify that despite the extensive alteration of the material the surfaces still had mirror polished areas. The perforation is biconical; part of the edge and the end of the heel have been broken since the discovery of the artefact, but the restoration conducted by the owner took into account the original morphology $(\mathrm{L}=20.4 \mathrm{~cm} ; \mathrm{W}=4.21 \mathrm{~cm} ; \mathrm{T}=1.45 \mathrm{~cm}$; diameter of the perforation on the upper face). After a new macroscopic examination in 2018, nephrite was also discarded as the raw material for the axe, and Pierre Pétrequin pointed out the possibility of the rock being made of amphibolite. Due to the impossibility of carrying out a spectroradiometric ana-

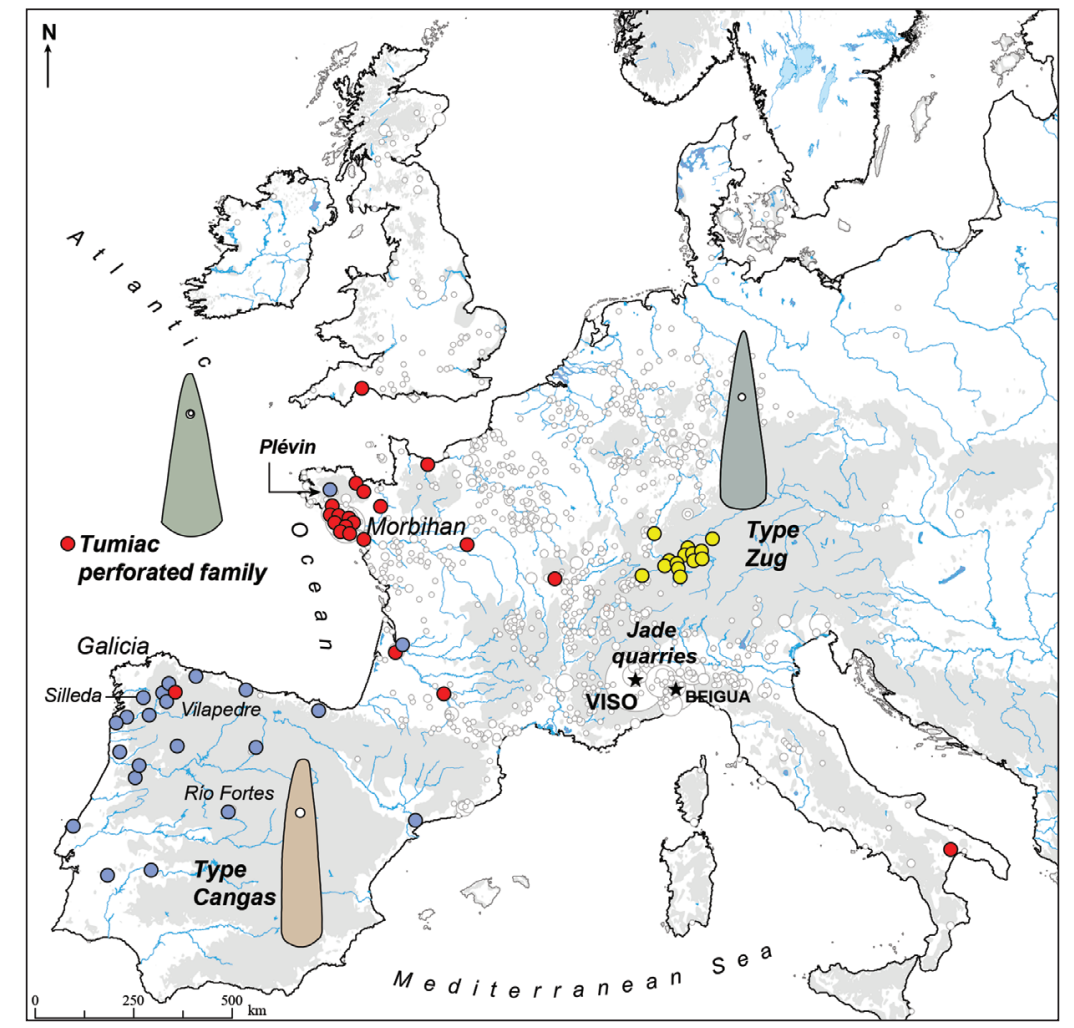

Fig. 2. Distribution of the axes of the Tumiac perforated family made on Alpine jades, compared to the Zug type and the Cangas type; localization of the axe of Plévin (after Pétrequin et al. 2012, and Fábregas Valcarce et al. 2012, supplemented). 
lysis (the owner not allowing the movement of the piece), a series of pXRF analyses were therefore conducted on the surface of the axe. At the same time and for comparison purposes, measurements were taken on the nephrite ring of Languidic (Morbihan) that is in the museum of Carnac (Fig. 4). This bracelet was considered for a long time to be made of serpentinite, but it turned out to be a piece of retromorphosed nephrite, similar to that of the Valais sources (Pétrequin et al. 2015). In the absence of reliable references for Europe, the issue of nephrite is difficult to address; still, after the analyses had been conducted, the idea of nephrite as the raw material was discarded for the Rest Louët Cangas-style axe. The pXRF results $(\mathrm{Si}=25.80 ; \mathrm{Mg}=13.24 ; \mathrm{Ca}=$ $8.30 ; \mathrm{Fe}=3.02 ; \mathrm{Al}=0.41)$ are compatible with those of a calcium amphibole.

Unfortunately, the geological origin of that piece cannot be ascertained for now, since the sources are quite diverse in Western Europe. However, in order to find similarities with the Plévin axe, we must turn to the Iberian Peninsula. The Spanish objects chosen for comparison (Fig. 3) came from Río Fortes - made of sillimanite - and Silleda - made of actinolite (part of the calcium amphibole group). The latter is not a perforated blade, but its appearance is quite similar to that of the axe found in Brittany. Regardless of the raw material, the axe from Plévin obviously contributes to the open discussion regarding the transfer of objects during the Neolithic, particularly along this plausible maritime route between Galicia and southern Brittany. The location of this object, still unique in Western France, is not trivial either, since it is at almost the exact meeting point of the departments of Finistère, Côtes-d'Armor and Morbihan, this is therefore - one of those important topographical points in connection with the sharing of waters, which are known as neuralgic places in the landscape, subject to all kinds of dangers and therefore requiring protective object (Cassen 2014). This apparently 'terrestrial' location of the Plévin axe must therefore be reviewed in the light of these natural outlets in the English Channel and Atlantic.
Variscite and turquoise beads and pendants

These semi-precious rocks are, of course, one of the emblematic materials among the Carnacean grave goods, such as those from Mané er Hroëck, which contains the largest number of pearls and pendants and the biggest average weight per object for the mid-5 ${ }^{\text {th }}$ millennium BC in Western Europe. The presence of variscite in France is attested from the beginning of the $5^{\text {th }}$ millennium $\mathrm{BC}$, but only in two tombs: Les Monts, in Plichancourt (Marne; Querré et al. 2008) and Lazzaro, in Colombelles (Calvados; Billard et al. 2014), both dating back to the latest Linear Pottery (Fig. 5; Cassen et al. 2019). These two pendants have an Andalusian origin (Encinasola, $\mathrm{Hu}$ elva). Far fewer pearls and pendants are found from the more recent Castellic phase, and - of course - only a small number of tombs from the beginning of the $4^{\text {th }}$ millennium BC still contain some of these items, especially in Poitou-Charentes, except for pendants.

To determine the origin of these objects, whose alleged source had been considered to be near Nantes (Loire-Atlantique), a series of analyses (PIXE, using the accelerator belonging to the Louvre Museum) were conducted on several hundred pearls and pendants (Querré et al. 2008). For comparison purposes and with the aim of developing a reference system, natural samples from French and European occurrences were analysed under the same conditions. The conclusions reached (Querré et al. 2019) are the following:
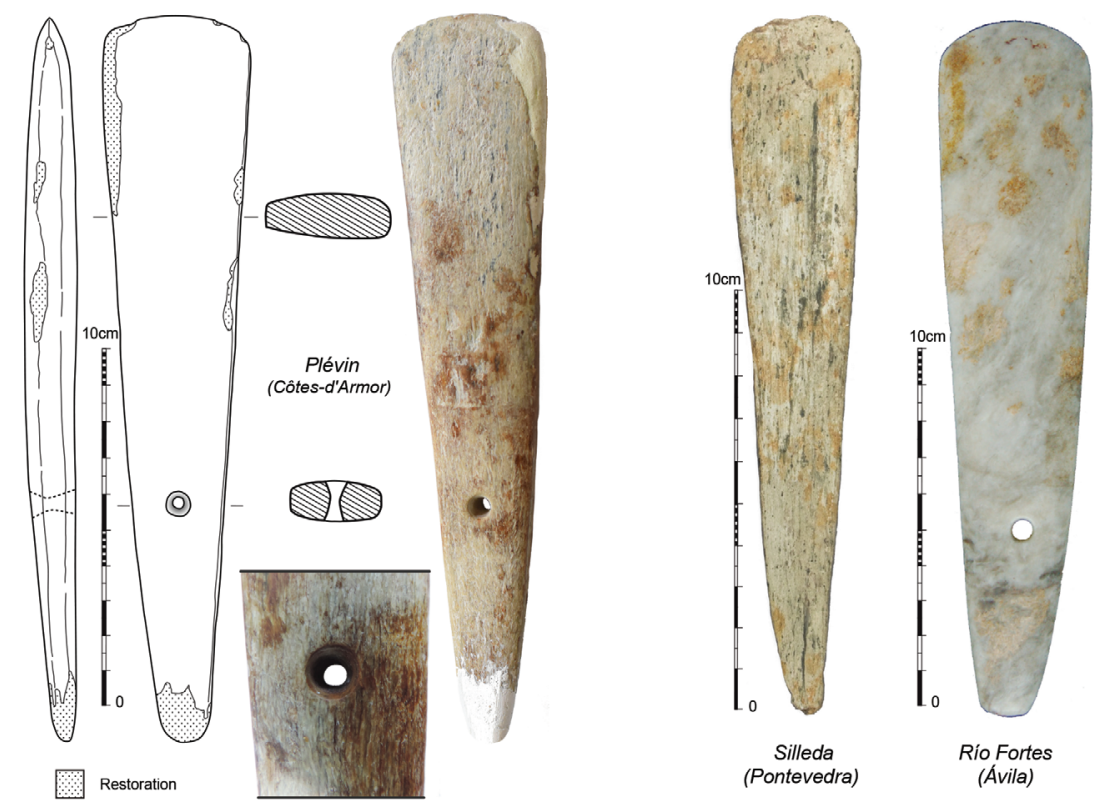

Fig. 3. Comparisons between the polished axe from Plévin (Côtes-d'Armor; drawing E. Roy, photographs B. Schulz Paulsson) and the axes from Silleda (Pontevedra) and Rio Fortes (Ávila), after Fábregas Valcarce et al. 2012 (CAD by S. Cassen). 
- None of the beads came from variscite sources known in France;

- Every piece found in Armorica came from Iberian sources, but not from the classic and expected one (Can Tintorer, in Catalonia), but in the earlier periods from those of Encinasola, in Andalusia, $1600 \mathrm{~km}$ from Morbihan, or from Palazuelo de las Cuevas, in Zamora province.

\section{Ceramic signs}

The Castellic pottery (L'Helgouac'h 1971) is distributed across the South Armorica area and recalls the monumental contexts described above. Approximately 50 domestic and funerary sites make up a collection otherwise little analysed during the $20^{\text {th }}$ century, given the impossibility of reconstituting vessels like those from the passage graves that were (and remain) the main source of information about the Neolithic (from 1890 to 1990). The excavation of the Lannec er Gadouer mound (Boujot, Cassen 2000) and the works on the set of stelae close to the Grand Menhir (Cassen et al. 2009) helped to narrow the chronological range of Castellic's two phases (4600-4300 and 4300-4000 BC).

Taking into account the secondary transfers originating from the Morbihan area detected when analysing some objects-symbols (weapons and adornments), the next logical step is to focus on the pottery. This is considered to evolve more quickly (in terms of both morphology and decorative patterns), while seldom moving across long distances. However, the ceramics in the Channel Islands seem to be directly related to the Morbihan tradition, using specific decorative techniques (including the common use of seashells of Gibbula magus and Mytilus edulis on the carenes and necks of the vessels - Cassen, François 2009). This relative similitude suggests a remote relation probably based on seafaring. The existence of maritime connections on the grounds of similar pottery traditions was also suggested by Childe (1932), who noted the relationship of the interlocking arches obtained by grooving among the vessels of the tomb of Mané Hui (Carnac) and those from Beacharra in Scotland, or in the funerary monument of Fontenay-le-Marmion (Calvados). We must bear in mind, however, that other approaches put forward by this author are today considered without foundation. Most researchers discredited this diffusionist model and justly criticize such decontextualized comparisons of ceramic traditions, especially dubious when associated with ideological proposals (Bailloud 1975).

Turning to southwestern Europe, other ceramic signs lend support to our case. A vessel found in the tomb of Dombate in Cabana de Bergantiños (Spain - Bello Diéguez 1997) poses another interesting question. Originally classified as a Bell Beaker by the excavators, it was subsequently linked to the early Neolithic assemblages of the Paris Basin (Suárez Otero 1997.492). In fact, both parallels were established without conducting the relevant comparisons with the records of these two chronological horizons ( $\mathrm{Cas}$ sen et al. 2012). Several arguments favour a Castellic model for this pot: a carinated shape, a concave

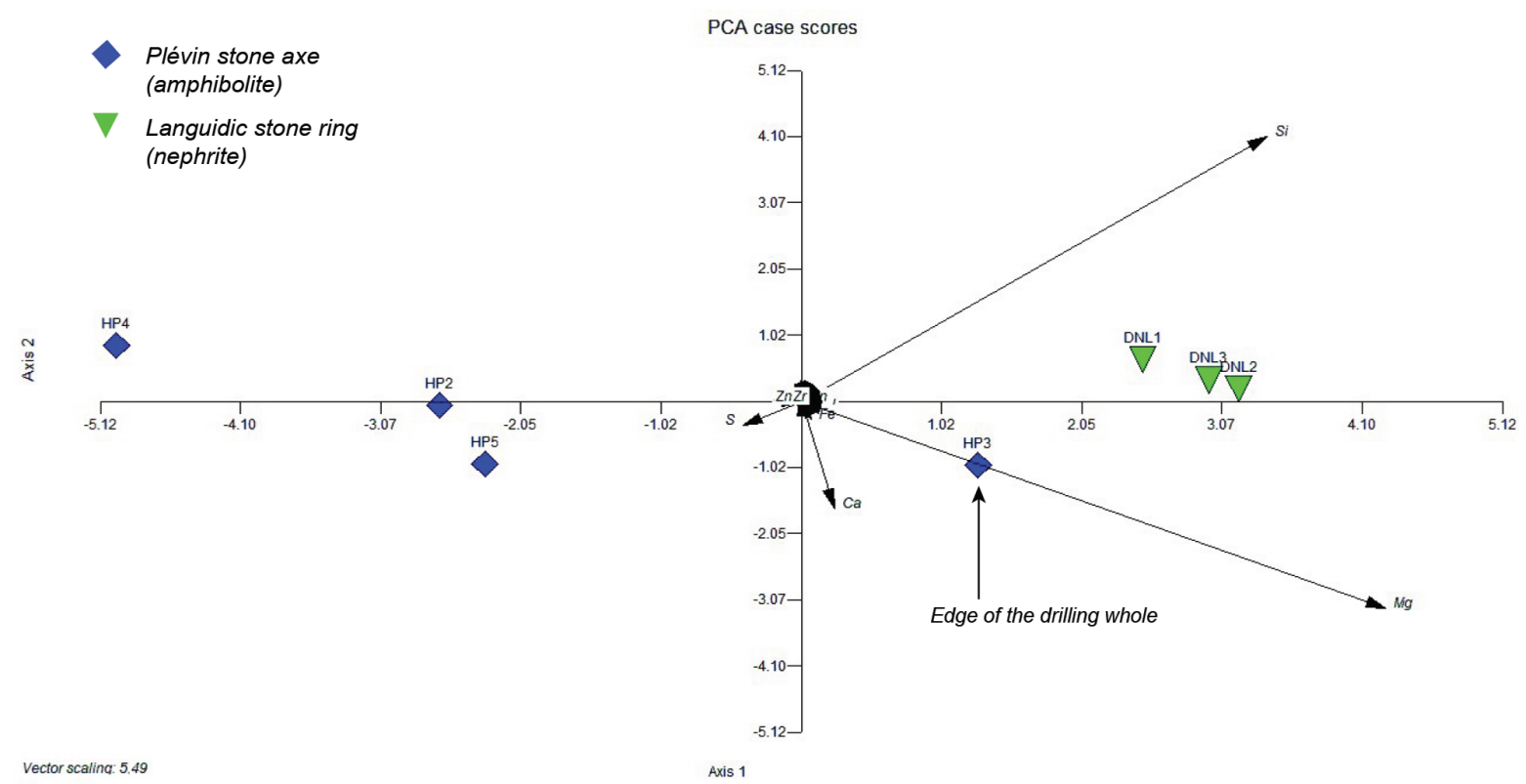

Fig. 4. Principle component analysis of the elemental composition of the Plévin axe (Côtes-d'Armor, France) compared to the nephrite reference material based on PXRF measurements. 
neck and the carination itself marked by horizontal lines made of punctuations done by using the apex of Hinia reticulata, one of the two types of shell used at Lannec er Gadouer, the Table des Marchands and $\mathrm{Er}$ Grah, just to confine ourselves to recently studied Castellic assemblages in Morbihan. This vessel goes back to the first stage of Dombate's funerary architectural design, going back at least to 3800 $\mathrm{BC}$, according to the ${ }^{14} \mathrm{C}$ dates. Whatever the status of this vessel (transfer, imitation, reinterpretation), it offers additional evidence of direct relationships with Morbihan that the engravings on the slabs of Dombate definitely confirm.

But before approaching the representations on monoliths, we must stress the existence of decorative motifs in pottery that could support our investigation of maritime relations. Three sites in Brittany will be compared: two of them provided vessels with a similar morphology and decoration, the third offers a graphic equivalent, but this time engraved on the wall of a burial chamber.
Carn and Guennoc Islands (Finistère, France)

Carn Island is famous for preserving a Neolithic cairn covering three fairly well-preserved burial chambers dating back to the early $4^{\text {th }}$ millennium BC (Giot 1987). In the central tomb, a thin-walled vessel is decorated with a 'moustache' that has been interpreted merely as a handle. We propose to compare this 'crescent' shape to a similar figure recently discovered on another island in this same geographical area, Île Guennoc, which is equally famous for preserving several cairns and chambers of remarkable height. From the fifteen or so known chambers, only one engraving - heavily eroded - has been 10cated at the chamber B of cairn II, seemingly representing a quadrangular pattern and, above all, a meander carved beside a large sign - a portion of a disc - that we relate to the 'crescent' shapes interpreted as 'unmanned boats' (Cassen 2007).

With the aim of ensuring these analogies, we will focus on another vessel discovered in the South-Armorican coastline. In Kervihan (Saint-Pierre-Quiberon),

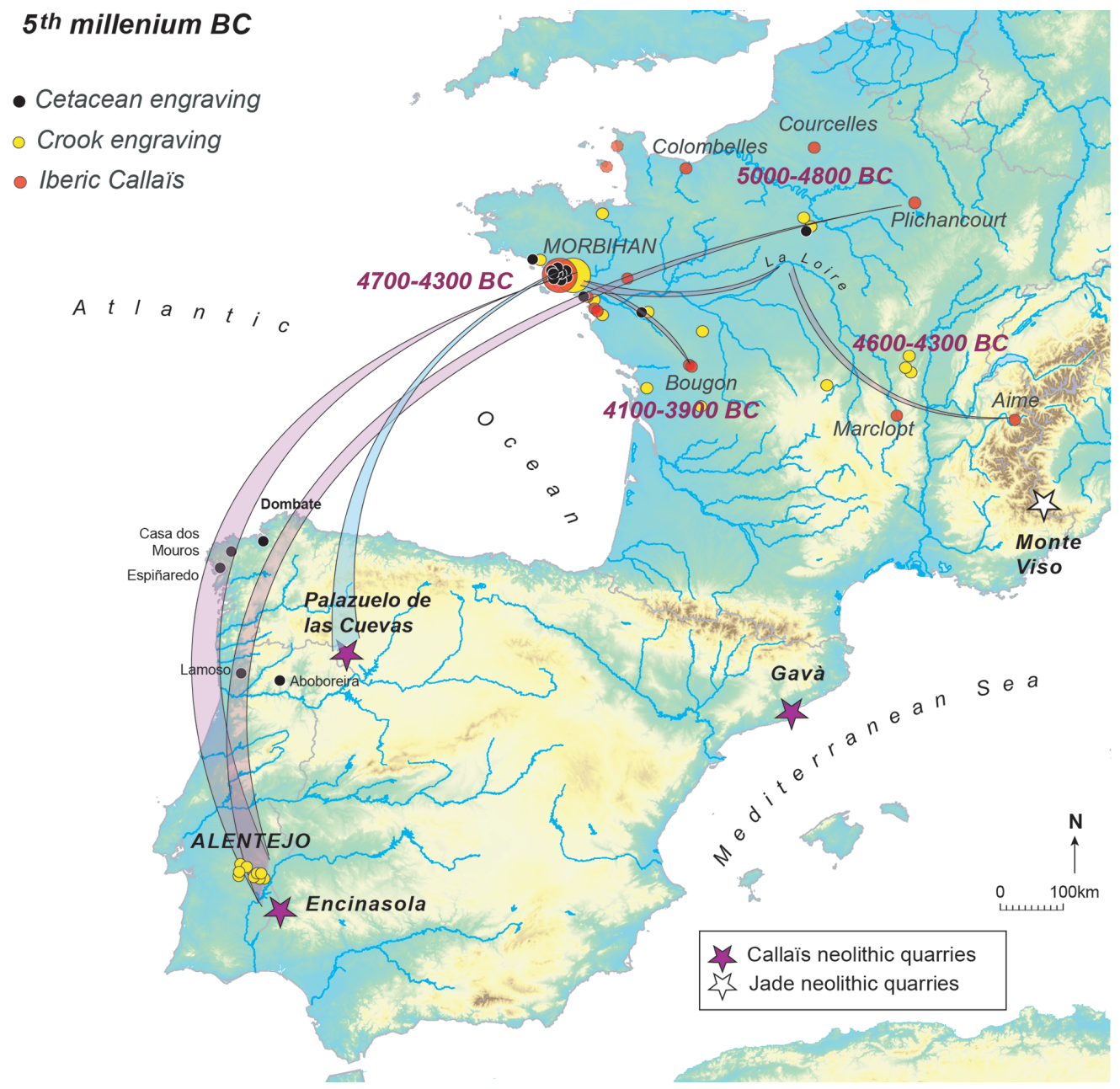

Fig. 5. Origins of the Callais in Neolithic tombs and depositions of northern France; Western-European distribution of the 'crook' and 'cetacean' signs (after Cassen, Vaquero Lastres 2000; Cassen et al. 2019). 
$5 \mathrm{~km}$ southwest of Carnac, $200 \mathrm{~m}$ from the sea and exactly on the watershed divide between the Atlantic side to the west and the Bay of Quiberon to the east, a set of about forty stelae was still standing around 1868, before farmers destroyed most of them. In 1888 , only three of them remained intact, including a $6 \mathrm{~m}$ long example (Lavenot 1888). While digging at the foot of one of these, Abbé Collet discovered a vessel (Closmadeuc 1868), and we are reproducing his drawing here for the first time (Fig. 6; Vannes Museum, ref. IM0418). A decoration of wavy lines, a typical Castellic technique, can be identified in three successive execution phases: (1) a first wave
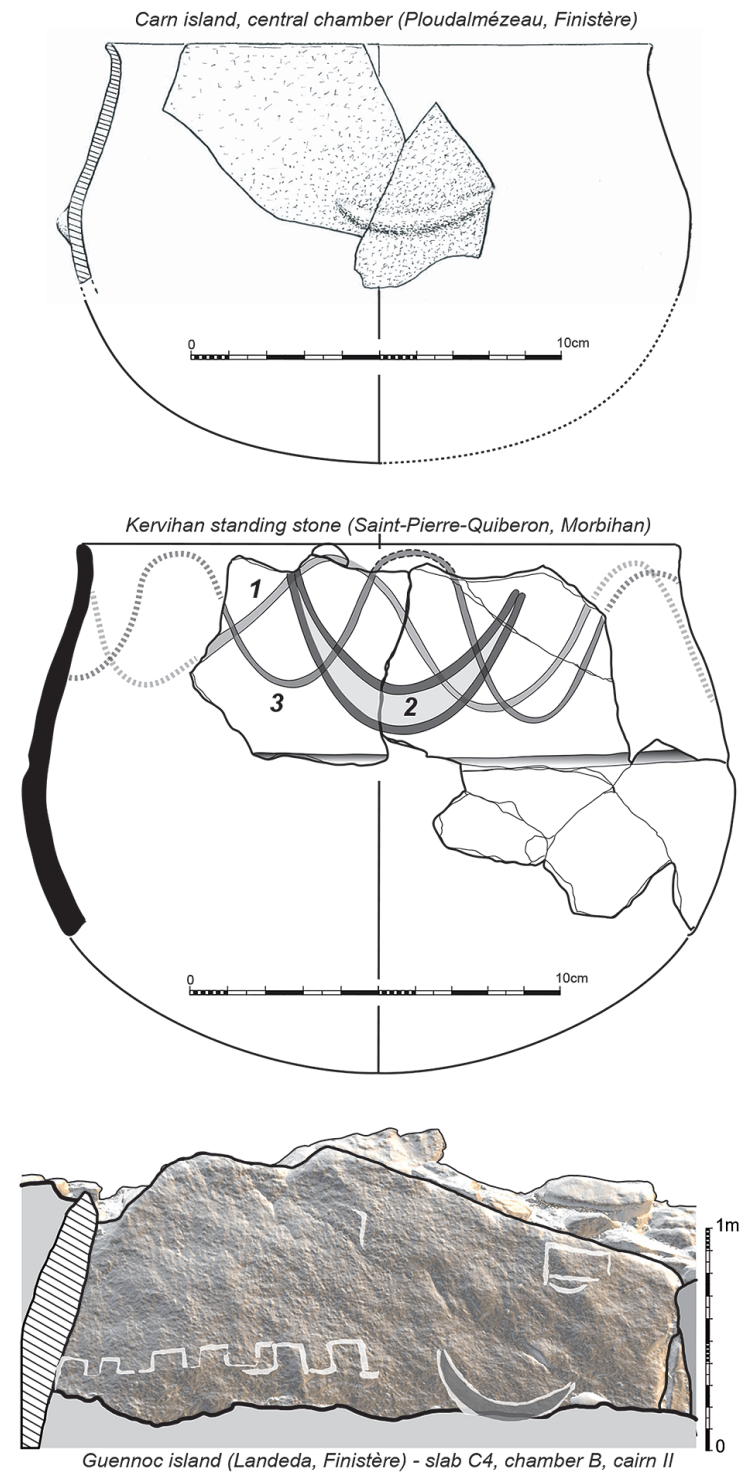

Fig. 6. The 'crescent' sign on Middle Neolithic ceramics from coastal Brittany: Carn island, central chamber (Ploudalmézeau, Finistère; after Giot 1987), Kervihan standing stones row (Saint-Pierre-Quiberon, Morbihan - Vannes Museum n ${ }^{\circ} 418$ ), Guennoc island, slab C4, chamber B, cairn II (Landeda, Finistère) (CAD by S. Cassen). sign was drawn on the neck, above the maximum diameter underlined by a large groove; (2) two curved lines are subsequently incised, joined by their ends in order to form a portion of a disc, or "crescent'; (3) a second wavy sign was then superimposed, offset with the previous one. There is no doubt that this 'crescent' motif is autonomous, not simply a rough assembly of lines. We believe this portion of disk to be the representation of an unmanned boat. Thus, the image in high relief from Carn island is represented here in a carved-out version. In spite of such a technical difference, the existence of a same intention of representation in two distinct ceramic traditions of the late $5^{\text {th }}$ and early $4^{\text {th }}$ millennia and echoed by the figures engraved on stelae, seems a plausible conclusion.

\section{Stelae and symbolic representations}

Another dimension of the proposed problem can be addressed through the analysis of the standing stones. As it is well known, assembled in straight or curvilinear lines, many of these structures are located in close contact with Carnacean tumuli, as in Mané er Hroëck, or keeping a more distant relationship, as in Mont Saint-Michel and Tumiac. Of course, the spatial juxtaposition of these exceptional monumentalities is part of the process of distinction and unproductive expenditure that is specific to this part of the Brittany coast in the mid-5th millennium BC.

In addition to this architectural dimension, we must take also into consideration the issue of the engraved symbolic representations. This part of the phenomenon has long remained difficult to tackle due to the reuse of stelae in the passage graves of the early $4^{\text {th }}$ millennium BC. Let us therefore continue our comparison based on these iconographic programs, essentially chosen because of the similarities found between Morbihan and the western areas of the Iberian Peninsula.

\section{Materials}

A detour in Morbihan, focused not on the signs but on the material used, is essential before considering the 'technical' possibility of these long-distance contacts. Thus, the orthogneiss - a coarse-grained granite - employed as raw material for the largest stelae of Arzon, Crac'h, Saint-Philibert and Locmariaquer (Querré et al. 2006; Bonniol, Cassen 2009) has its closest source at the Rhuys peninsula (Pen Castel). The challenge posed by the majority of the blocks is not the distance covered during their transportation (5 or $10 \mathrm{~km}$ as the crow flies is not an exceptional distance among European megaliths) but the weight 
transported, as in the case of the 330t of the Grand Menhir. In addition, there are the deep rias with strong tidal currents that had to be crossed.

The feat is even more obvious in the case of the Runélo stela, weighing between 27 and 29t, transported to the summit of Belle-Ile-en-Mer, $60 \mathrm{~km}$ as the crow flies from its geological source, and at least $40 \mathrm{~km}$ offshore. Like the Grand Menhir, such a displacement cannot be conceived by simply resorting to dugout canoes, even if these were juxtaposed, as pointed out by Le Roux (1997). We thus must suggest that these populations must have mastered relatively complex naval techniques (e.g., sewn panel boats) in order to carry such a heavy cargo during open sea navigation (Cassen et al. 2016).

\section{The depictions}

The image, nowadays as in the past, if it is 'thought', is not and cannot be reduced to the sole function of being an illustration. We therefore consider the image as an instrument of investigation, and - consequently - as a tool for producing knowledge of reality (Péquignot 2006.48). Among the European inventory of the least ambiguous motifs, seven types of engravings present on monoliths will be used to enrich our comparison.

\section{The 'crook'/a throwing stick}

This sign is the most frequent within the Armorican corpus, and it is very often associated with the depiction of hafted polished blades.

With the possible exception of reused slabs in the Bronze Age burial mounds of Old Parks, Kirkoswald (Cumbria), which would require a new survey in order to confirm the similarity of their crooks with the models in Western France (Beckensall 1999.135), this sign is known only on the stelae located in the Algarve and Alentejo regions, in Portugal (Calado 1997; Gonçalves 1999; Gomes 2011). The relationship with the Armorican specimens was suggested early on (Siret 1920). In this sense, a similar positioning of the instrument on the surface of the monoliths can be noted in both regions (Fig. 7). As in Brittany, the sign described in Portugal should be understood as a throwing stick and not as the shepherd's peaceful instrument.

\section{The 'square'/the representation of a space}

This sign, present on the Armorican stelae as well as on the orthostats of passage graves, was usually depicted as though 'leaning' (with respect to a horizontal axis parallel to the ground), creating an undeniably dynamic effect, often under the noticeable action of a mobile neighbouring sign (crook, croissant-boat).

The most obvious analogies lead us once again to the Alentejo (Fig. 7), where the usual tendency towards anthropomorphism lends it the function of a 'nose' (Gomes 1997a). The representation of a space seems to be a more likely hypothesis, no matter for the moment whether it is a territory, an island, a parcel or a dwelling.

\section{The 'crescent'/an unmanned boat}

Often assimilated to bovine horns by Breton archaeologists, we have compared this sign to what Gustave de Closmadeuc called the 'pectiniform' in 1873. Adrien de Mortillet interpreted such pectiniform as a 'boat with crew' in 1894 . We therefore bring these two graphic forms close together simply due to the fact that they share the sign of the boat according to two quite distinct, even opposite, regimes of representations in the universal history of human societies (Cassen 2007): on the one hand a boat with crew, with a figure systematically dominating the

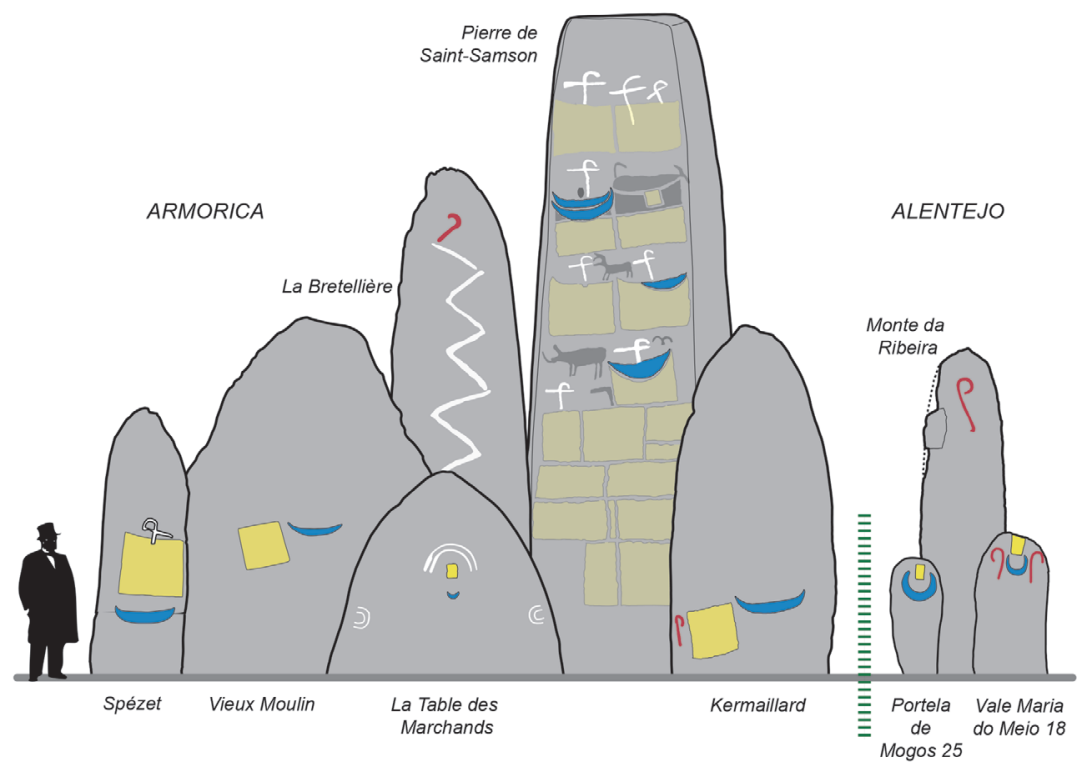

Fig. 7. Comparisons of some signs engraved on the stelae of the $5^{\text {th }}$ millennium BC in Morbihan (France) and Alentejo (Portugal) (after Cassen 2007; Gomes 2010; Cassen et al. 2017). 
others; on the other, a boat without oars or crew. We argue that the truncated disc represented in some Alentejo steles is equivalent to an unmanned boat, all the more so since its association with the quadrangular sign, as well as with the crook sign, reinforces the connection, going well beyond the formal similarities of simple geometric arrangements.

\section{The 'axe plough'/a sperm whale}

The 'axe plough' is a major sign within the Armorican megalithic art corpus. Its different graphic units have been deconstructed in order to understand and place them better within a process of recognition that takes into consideration the space occupied by the sign, its structural relationship with neighbouring signs and the geographical and archaeological context of the findings (Cassen,Vaquero Lastres 2000; Whittle 2000). Not simply a cetacean, but a sperm whale may be precisely identified.

In order to ensure the archaeological coherence of this hypothesis, we have tried to find a similar dy- namic line in the European record, and it was towards Galicia and northern Portugal that the best connections appeared, through a sign called 'The Thing' (Shee Twohig 1981). The already mentioned passage grave of Dombate is of great interest in this respect, as it reproduces several components of the Morbihan model: (1) superimposition, around 3800 $\mathrm{BC}$, of a passage grave over an earlier mound surrounding a tomb without permanent access; (2) reuse of stelae as slabs; (3) stelae depicting a group of cetaceans (Fig. 8).

\section{The bow}

Until now, the depiction of this throwing weapon was confined to the Armorican peninsula and the Channel Islands (Guernsey), always inside passage graves and twice in a clearly secondary position (Ile Longue, Le Déhus). The painted representation in the Juncais passage grave (Portugal), where a hunting scene with an archer was depicted, is of uncertain date (Shee Twohig 1981) and we will wait until it is better established.

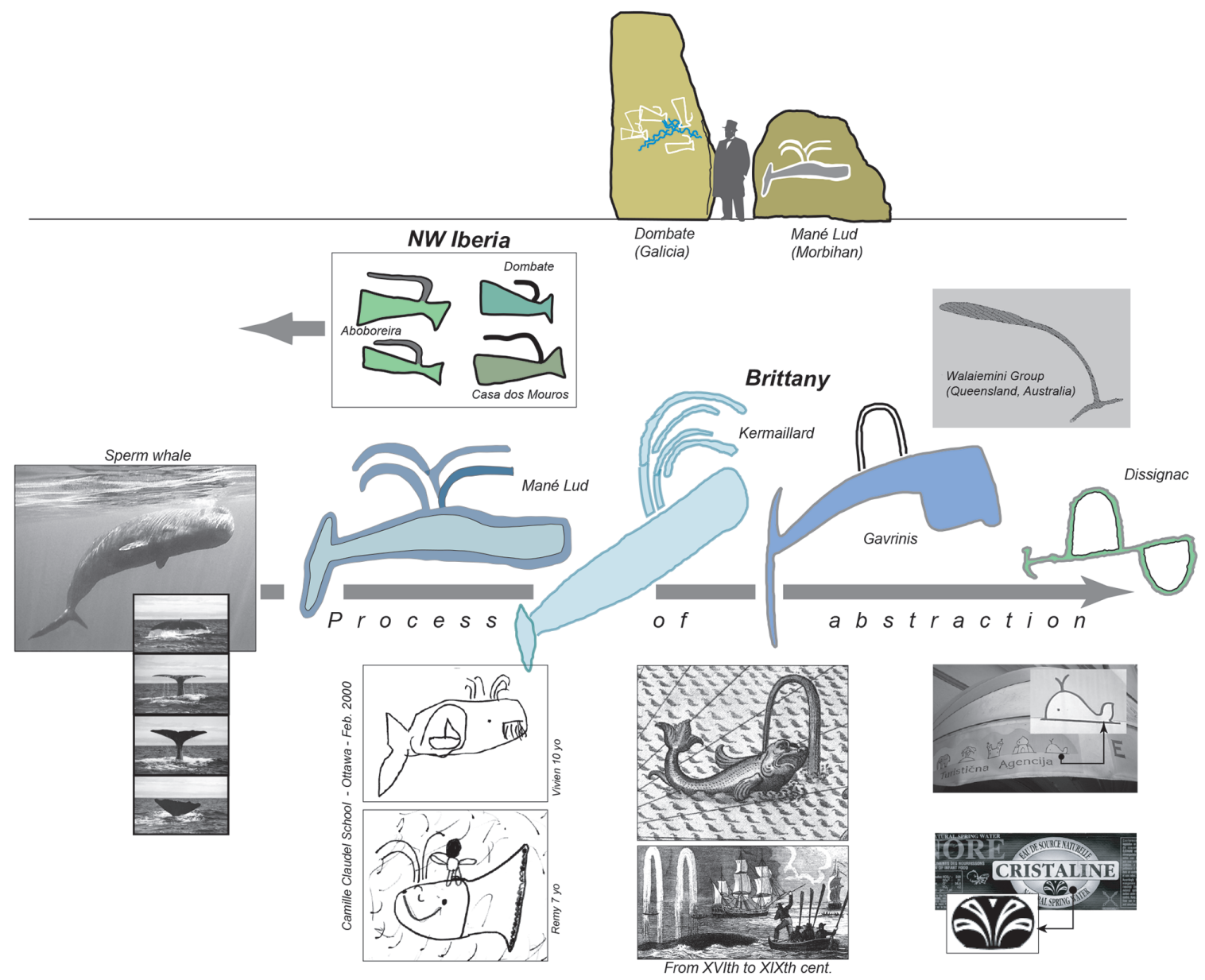

Fig. 8. Variations and diversity of cetacean engravings (sperm whales) on re-used stelae in the passage tombs of north-western Iberia and Western France. Comparisons of some significant graphic units in the current world of the representations (after Cassen, Vaquero Lastres 2000; Cassen 2007). 
However, the careful survey of monolith № 10 of Vale Maria do Meio (Alentejo) has allowed us to identify a bow for the first time, an object similar to those existing in the Armorican repertoire (Cassen et al. 2015). Not only its design matches exactly that of the l'Ile Longue in Morbihan (Fig. 9), but the direct association with the 'crook' and 'square' signs in the same composition (Calado 2004) follows a pattern similar to that found on orthostat 13 of Mané Kerioned B, in Carnac.

\section{The 'mother goddess' a phallus}

Very few standing stones in Brittany offer a naturally phallic aspect (Barnenez H, Kermaillard), and none do so explicitly during the $5^{\text {th }}$ millennium BC, i.e. carved with realistic anatomical details. The only possible exception is a monolith with a decorated end, discovered in the extension of the Early Neolithic house of Le Haut Mée (Cassen et al. 1998). In contrast, the engraving usually known as 'shield divinity', 'mother goddess', etc., considered to be a female being since the 19th century (Gimbutas 1989. 247; Briard 1991.184; Le Roux, Lecerf 2003.26; Mohen 2009.101, 137; Sergent 2011.35), sometimes an indeterminate entity between female and male (L'Helgouac'h 1991.543), will be reinterpreted as a phallic form, much more consistent with the original architectural context and in accordance with the structural analysis associating the other signs (Cassen 2000).

The standing stone, explicitly shaped for phallic representation (glans, meatus), is present in Galicia (Gargantáns), but even more visible in southern Portugal (Gomes 1997; 2011) and may be dated back to the $5^{\text {th }}$ millennium $\mathrm{BC}$ despite the uncertainty of their stratigraphic contexts (Calado et al. 2003). Wavy lines, interpreted as snakes, are frequently reproduced vertically along the length of the penis.

\section{The snake}

Without always achieving the degree of fidelity to the true animal that we recognize in Gavrinis or Manio 2 in Morbihan, the Portuguese snakes engraved on stelae (Gomes 1994; Bueno Ramirez, Balbin Behrmann 1995) are indeed an additional element to be added to the semi- otic comparison. We would like to extend the analogy to all those regions along the European Atlantic coast where it is present, Galicia as well as the areas around the Irish Sea, but because of its banality and geometric simplification, which may lead to confusion with the representation of water, we will not dwell on this topic here.

Summing up, several of the essential signs of the Morbihan corpus of megalithic art dated back to the first half and mid-5th millennium BC are also identified in Galicia and Portugal, not in isolation and on the basis of vague similarities but within relations of opposition and complementarity shared between these regions, excluding - in the present state of knowledge - the other sectors of the Spanish (Asturias, Cantabria, Basque Country) and French (Aquitaine, Charente) coasts.

\section{The charm of the sea}

Through weapons and ornaments diverted from their function, then through pottery decorations and symbolic representations on standing stones, several combined arguments contribute to establish a direct, verifiable relationship between Morbihan and the westernmost Atlantic coast of the Iberian Peninsula from the mid-5th millennium BC. So far, no comparable intermediate parallels are known on the coasts of the Gulf of Biscay. Therefore, since the existence of coastal navigation has been clearly accepted in those areas (Callaghan, Scarre 2009; Fábregas et al. 2012; Philippe 2018), we must also consider, as a matter of principle, that maritime relations, even those exceptional and more or less di-

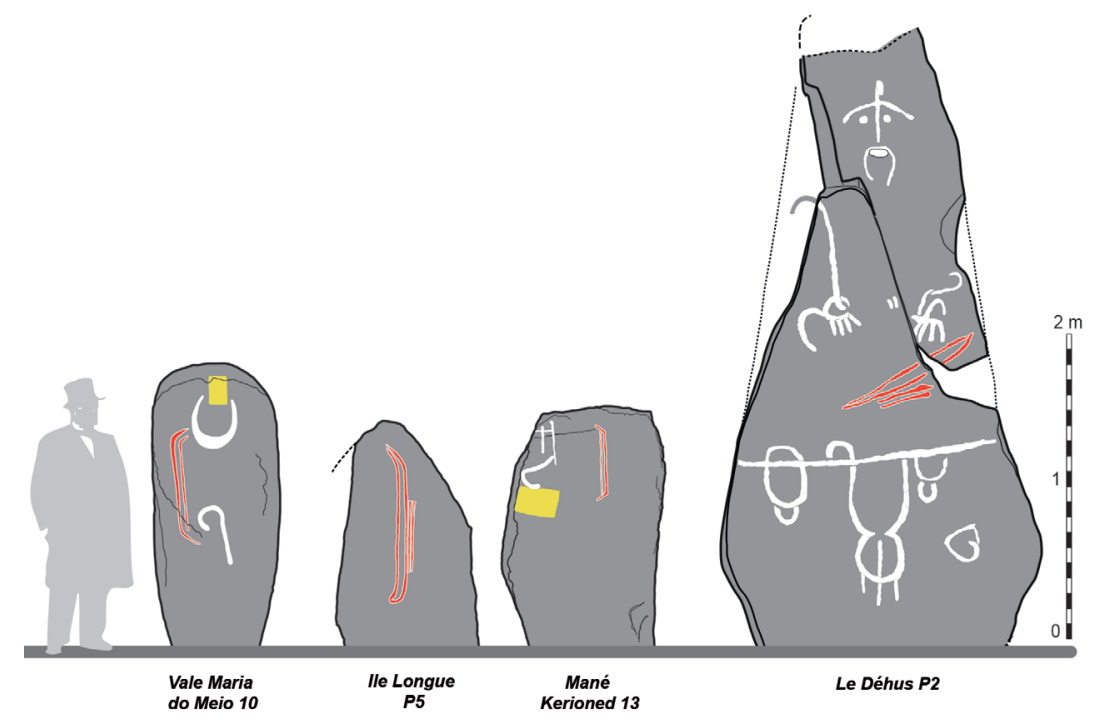

Fig. 9. Similar representations of a bow on Neolithic stelae of Alentejo (Portugal), Morbihan (France) and Anglo-Norman islands (the UK) (after Cassen et al. 2015). 
rect, took place between these regions in the Neolithic. Although still hypothetical at that time, the existence of a direct route between Cape Ortegal and Southern Brittany is referred to by classical authors (Strabo I. 4.5 and Tacitus in Agricola 10 and 11). The 'Arimaspea', a poem written around the $7^{\text {th }}$ or $6^{\text {th }}$ century BC, or the Phoenician sailors leaving Cadiz/Tartessos at the beginning of the $1^{\text {st }}$ millennium $\mathrm{BC}$, are also testimonies in favour of these Atlantic voyages to Northern Europe (Plumet 2004). In other words, this direct route (depending on the seasons), accepted for the Late Bronze and the Iron Age, implies an older human experience.

In this respect, Galicia probably played an important role as a crossroads of communication routes from the interior (towards the variscite mines of the $\mathrm{Za}$ mora region, sillimanite from the mountains north of Madrid), or by coast from Andalusia (variscite mines of Encinasola) via Portugal and the key region of Evora. In Galicia, the funerary mounds of Forno dos Mouros, Chousa Nova and Illade 0 are worth mentioning for three main reasons: they are not passage graves; they contained variscite ornaments, a jadeite pendant, polished axes made on sillimanite, and lastly - a long, polished adze planted vertically; while being dated back to the 4500-4300, 4300-4200 and 4300-4000 BC, respectively (Mañana Borrazás 2005; Dominguez-Bella, Bóveda 2011; Vaquero Lastres 1999).
This link between Southern Armorica and Galicia is visible, from an archaeological point of view, two or three centuries after a relationship can be indirectly guessed. Such phenomenon of delayed chronology could of course be repeated in the British Isles and Ireland. The fragment of a perforated schist bracelet found at Peak Camp (Darvill et al. 2011), only 10km from the Severn Estuary facing the Irish Sea, clearly refers to an ornament specific of the Early Neolithic period in northwestern France. It alone testifies to this palimpsest that is so difficult to decipher (of course, the similar 'pendentifs arciformes' of the Paris basin are late Neolithic).

The reader may therefore understand that the quest for the physical object, or for the appropriate and accurate archaeometric measurement, is not enough to construct a historical scenario. And, if crossing the English Channel or the Irish Sea did not pose any problems in the $4^{\text {th }}$ millennium BC (Garrow, Sturt 2011), why couldn't it be the same during the $5^{\text {th }}$ ? Let us return to this possibility.

\section{"Océan. Tas de pierres"}

In his posthumous writings, dated between 1816 and 1883 and gathered under this poetic title, Victor Hugo stated that the greatest realities, the most complex, the true, the only ones perhaps, are logically those which are always and perpetually pre-

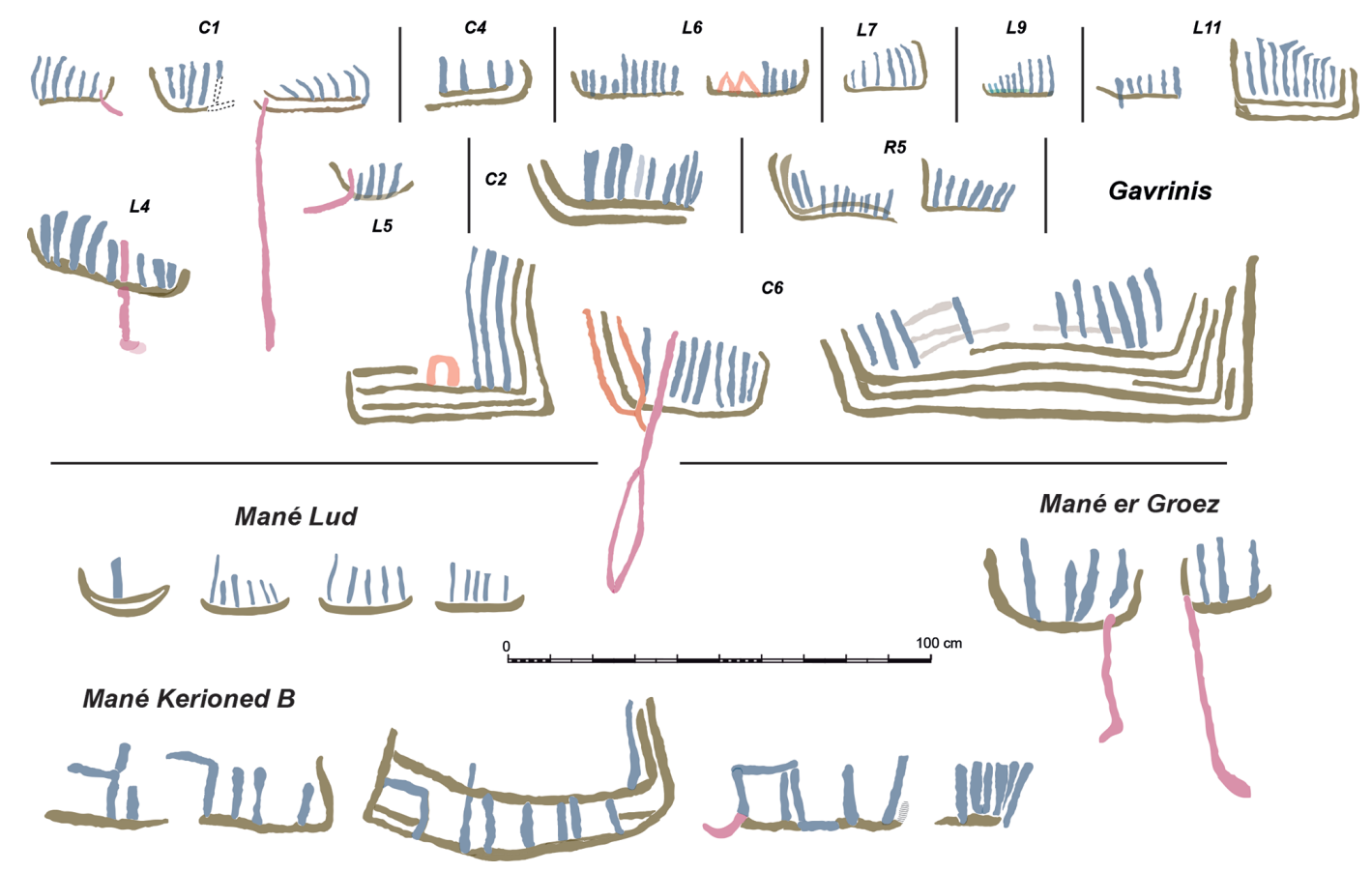

Fig. 10. Representations of boats with crew on the orthostats of the passage tombs of Gavrinis (LarmorBaden), Mané Lud (Locmariaquer), Mané er Groez and Mané Kerioned (Carnac) (after Cassen 2007; Cassen et al. 2017; Cassen et al. 2018, supplemented). 

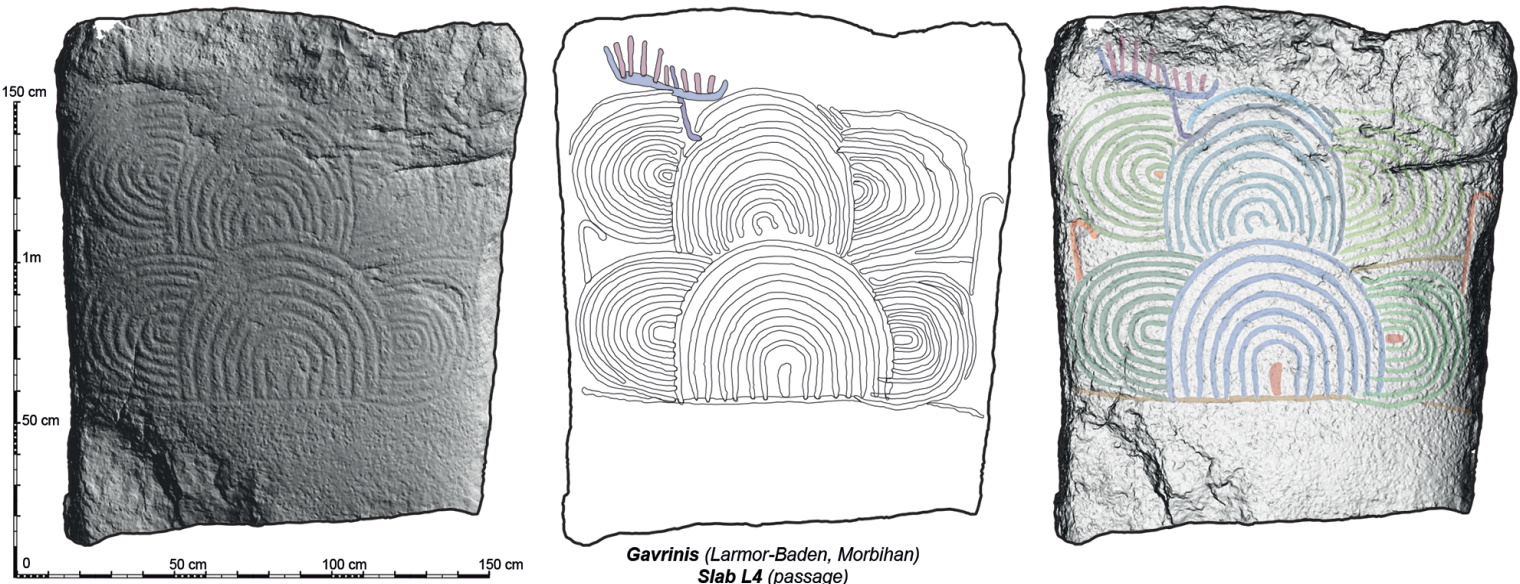

Fig. 11. Inscription of the 'boat with crew' pattern in the ornamentation of an orthostat in the Gavrinis passage tomb (Larmor-Baden, Brittany, France) (CAD and 3D model by S. Cassen, V. Grimaud).

sent, "there is no real thing but the ideal" (Hugo 1942.193).

We have previously pointed out how the transport of huge blocks raises the question of what kind of boats may have moved them at sea. Could the depictions of boats in Morbihan help us to conceive these trips? Let us recall the example of the orthostats of some Morbihan passage graves that preserve such symbolic figures (Fig. 10). It would be misguided to attempt to discover here the technical details of naval architecture ensuring the movement on the high seas, even if steering oars seem well represented. On the other hand, the depiction of a boat with crew and a steering oar, as if caught in a whirlwind (Fig. 11) present in the slab L4 of Gavrinis (Larmor-Baden), can - in turn - influence the inter- pretation of these concentric arcs that, by intuition, we had linked to the representation of water.

Beside this 'crewed' version, we have previously proposed that the 'crescent' depicted on several stelae in Morbihan could be interpreted as an unmanned boat. The latter interpretation - with or without standing humans in its interior - is present in both the Celtic mythology of Western Europe and in the Breton legends. Opposing life with death, it is crucial to think about the fundamental reasons for going to sea, real or ideal. In this respect, we must recall the text of Procope written in the 6th century: "The fishermen and other inhabitants of Gaul who are in front of the island of Brittany are responsible for passing through it the souls of the dead, and for this reason exempt from taxation" (The War of
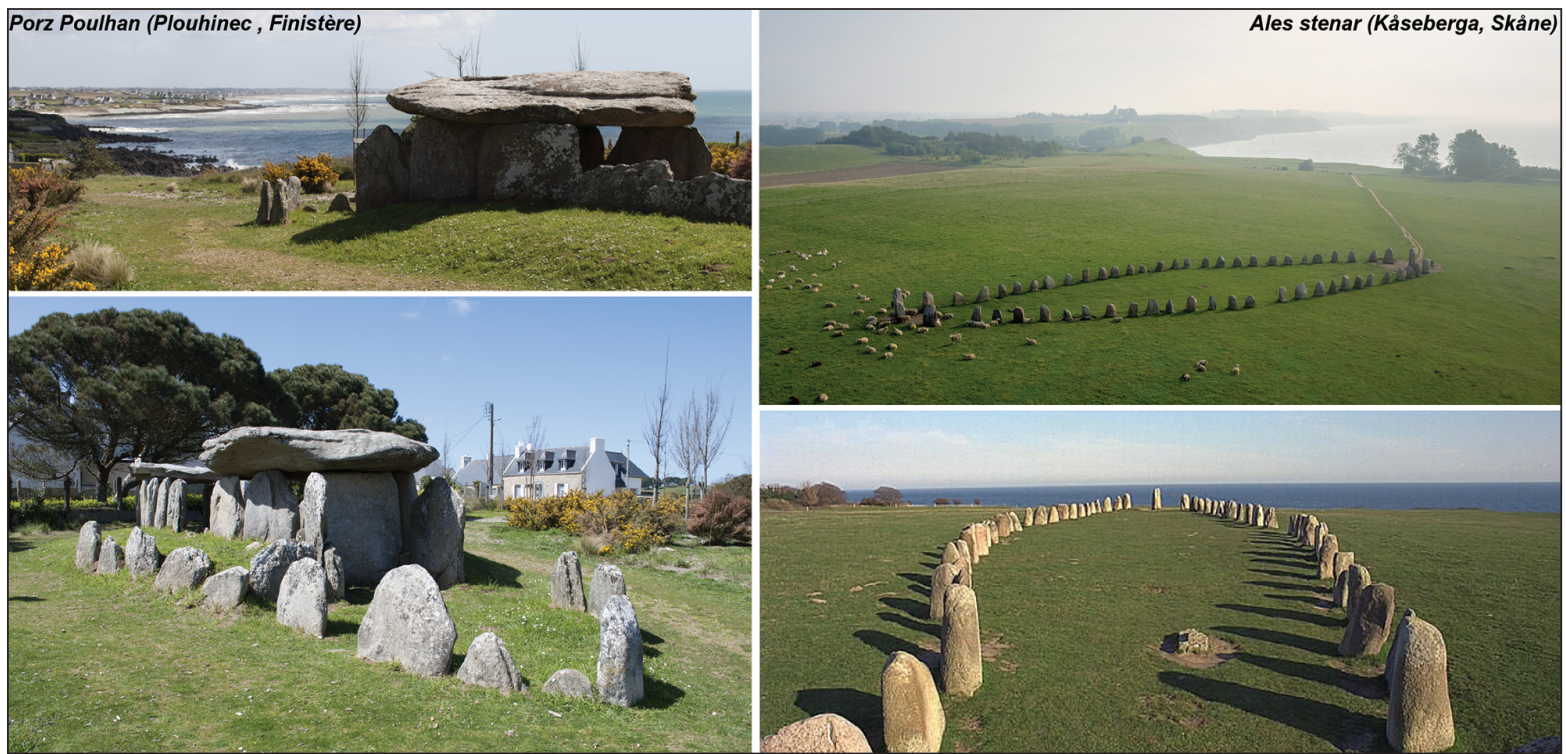

Fig. 12. Comparison between the naviform plan of the Neolithic tumulus and tomb of Porz Poulhan (Plouhinec, France; photos S. Cassen) and the probable Viking tomb of Ales Stenar (Kćseberga, Sweden; photos D. Bengtsson and B. A. Lundberg/Kulturmiljöbild, Riksantikvarieämbetet) (CAD by S. Cassen). 
the Goths 1, IV, c. 20). It is therefore likely that the funeral journey must have been a part of the world of representations of the Neolithic societies in Western Europe. In this respect, it is significant to point out that the 'naviform' plan of the burial mound surrounding certain tombs at the end of the $4^{\text {th }}$ millennium BC in Brittany is closely correlated with such a belief system. The Viking tombs in Sweden (ship settings), from the 6th century onwards, were built following a similar solution (Fig. 12).

Whether the journey is by river or sea, there is little doubt that the long-distance acquisition of socially valued goods may have granted a form of social prestige in compensation for the dangers involved in the journey. But we may also miss the essential, i.e. the charm of the sea, if we were to remain in search of a solely economic interest. The utility of sailing on the ocean is not clear enough to force prehistoric man to dig a canoe out of a tree trunk, to stretch animal skins on a pole frame, or to tie wooden boards together. No utility can legitimize the immense risk of entering the sea in order to approach another land for the first time. To engage in navigation, you need a powerful interest. However, the real powerful interests are the chimerical ones, the interests that we dream about, not those that we calculate. These are the fabulous interests. And what could be more fabulous than to experience the end of a life, to go and to explore the end of a world? ... Because the first sailor was the first living man who was as brave as a dead man (Bachelard 1942), and is not the hero of the sea also a hero of death?

It is often said that death is a journey and travel is a form of death ... "To leave is to die a little", says the French proverb. To die is really to leave, and one can only leave well, courageously, clearly, by following the course of the water, the current of the broad river joining the River of the Dead. Only this kind of death is fabulous, only this departure is an adventure. If for the unconscious, a dead person is really an absent person, only the navigator of death is a dead man who can be dreamed of indefinitely.

We thank Y. Ling and R. Chacon for their invitation and their excellent welcome in Göteborg University; P. Pétrequin kindly gave us a first visual diagnosis of the rock of Plévin, and C. Le Guern, Y. Cocoual and E. Vigier (Carnac Museum) allowed us to analyse this axe under the best conditions; the Kervihan vessel could be studied with the help of C. Le Pennec (Vannes Museum); the survey of the engravings at Guennoc benefited from a topographic survey led by $F$. Cousseau. Finally, many thanks to C. Obeltz for sharing the results of his surveys in the Quiberon peninsula. The authors must also acknowledge and express thanks to the anonymous reviewers for their comments.

\section{References}

Bachelard G. 1942. L'eau et les rêves : essai sur l'imagination de la matière. José Corti, 1978. Paris.

Bailloud G. 1975. Les Céramiques cannelées du Néolithique armoricain. Bulletin de la Société Préhistorique Française 72: 343-367.

Beckensall S. 1999. British prehistoric rock art. Tempus Publishing Ltd. Stroud.

Bello Diéguez J. M. 1997. Aportaciones del dolmen de Dombate (Cabaña, La Coruña) al arte megalititico occidental. In J. L'Helgouac'h, C. T. Le Roux, and J. Lecornec (eds.), Art et symboles du Mégalithisme européen. Actes du $2^{\circ}$ colloque international sur l'art mégalithique, Nantes 1995. Revue Archéologique de l'Ouest, Sup n 8. Nantes: 23-39.
Billard C., Bostyn F., Hamon C., and Meunier K. (eds.) 2014. L'habitat du Néolithique ancien de Colombelles Le Lazzaro (Calvados). Mémoires de la Société préhistorique française 58. Paris.

Bonniol D., Cassen S. 2009. Corpus descriptif des stèles ou fragments de stèle en orthogneiss. In Cassen S. (ed.), $A u$ tour de la Table. Explorations archéologiques et discours savants sur une architecture néolithique restaurée à Locmariaquer, Morbihan (Table des Marchands et Grand Menhir). Actes du colloque international, Vannes (Morbihan), 5-7 octobre 2007 (Université de Bretagne-Sud, campus Le Tohannic). Université de Nantes, Laboratoire de recherche Archéologie et Architecture. Nantes: 702-734.

Boujot C., Cassen S. 2000. Explorations du tertre de Lannec er Gadouer. Les fouilles de 1993 à 1997. In S. Cassen, 
C. Boujot, and J. Vaquero (eds.), Eléments d'architecture (Exploration d'un tertre funéraire à Lannec er Gadouer, Erdeven, Morbihan. Constructions et reconstructions dans le Néolithique morbihannais. Propositions pour une lecture symbolique). Asso. Publications chauvinoises, Mémoire 19. Chauvigny: 29-91.

Briard J. 1991. Des Déesses-Mères néolithiques au culte du guerrier de l'Age du Bronze du Bassin méditerranéen à l'Europe protohistorique. In H. de Lumley (ed.), Le Mont Bego, Une montagne sacrée de l'Age du Bronze. Institut de Paléonthologie Humaine. Paris: 513-536.

Bueno Ramírez P., Balbín Behrmann R. 1995. La Graphie du serpent dans la culture mégalithique péninsulaire. Représentations de plein air et représentations dolméniques. L'Anthropologie 99(2-3): 357-381.

Calado D., Nieto Liñán J. M., and Nocete Calvo F. 2003. Quinta da Queimada, Lagos, Portugal. Datação do momento de erecção de um monumento megalítico através da luminescência óptica de cristais de quartzo (OSL). In $V$ Congreso Ibérico de Arqueometría. Libro de Resúmenes de Actas. Universidad de Cádiz. Cádiz: 167-168.

Calado M. 1997. Cromlechs alentejanos e arte megalitica. In A. Rodriguez Cazal (ed.), IIe Colloquio Intern. de Arte megalitico, A Coruña, 1997. Brigantium 10: 289-297.

2004. Os menires do Alentejo Central. PhD thesis. Universidade de Lisboa. Lisabon.

http://www.crookscape.org/tesemc/tese.html

Callaghan R., Scarre C. 2009. Simulating the Western Seaways. Oxford journal of archaeology 28(4): 357-372. https://doi.org/10.1111/j.1468-0092.2009.00333.x

Camps G. 1976. La navigation en France au Néolithique et à l'âge du Bronze. In J. Guilaine (ed.), La Préhistoire française. Tome II : Les civilisations néolithiques et protohistoriques de la France. Editions du Centre national de la recherche scientifique. Paris: 192-201.

Cassen S. 2000. La Forme d'une déesse. In S. Cassen, C. Boujot, and J. Vaquero (eds.), Eléments d'architecture (Exploration d'un tertre funéraire à Lannec er Gadouer, Erdeven, Morbihan. Constructions et reconstructions dans le Néolithique morbihannais. Propositions pour une lecture symbolique). Asso. Publications chauvinoises, Mémoire 19. Chauvigny: 657-681.

2007. Le Mané Lud en images. Interprétation de signes gravés sur les parois d'une tombe à couloir néolithique (Locmariaquer, Morbihan). Gallia-Préhistoire 49: 197258 .

2012. La crosse, point d'interrogation? Poursuite de l'analyse d'un signe néolithique, notamment à Locma- riaquer (Morbihan). L'Anthropologie 116: 171-216. https://doi.org/10.1016/j.anthro.2012.03.006

2014. Sites de passage (1). Le modèle carnacois des pierres dressées à l'épreuve des rivières, des lacs et des montagnes (France, Suisse, Italie). In R.-M. Arbogast, A. Greffier-Richard (eds.), Entre archéologie et écologie, une Préhistoire de tous les milieux. Mélanges offerts á Pierre Pétrequin. Presses universitaires de FrancheComté, (Annales Littéraires de l'Université de FrancheComté, 928; série »Environnement, sociétés et archéologie«, 18). Besancon: 281-302.

Cassen S., Audren C., Hinguant S., Lannuzel G., and Marchand G. 1998. L'Habitat Villeneuve-Saint-Germain du Haut Mée (Saint-Étienne en Coglès, Ille-et-Vilaine). Bulletin de la Société Préhistorique Française 1: 41-76.

Cassen S., Vaquero Lastres J. 2000. La Forme d'une chose. In S. Cassen, C. Boujot, and J. Vaquero (eds.), Eléments d'architecture (Exploration d'un tertre funéraire à Lannec er Gadouer, Erdeven, Morbihan. Constructions et reconstructions dans le Néolithique morbihannais. Propositions pour une lecture symbolique). Asso. Publications chauvinoises, Mémoire 19. Chauvigny: 611-656.

Cassen S., François P. 2009. Classements et diagnoses de la production céramique à la Table des Marchands. In S. Cassen (ed.), Autour de la Table. Explorations archéologiques et discours savants sur des architectures néolithiques à Locmariaquer, Morbihan (Table des Marchands et Grand Menhir). Actes du colloque international, Vannes, Université de Bretagne-Sud, 5-7 octobre 2007. Université de Nantes, Laboratoire de recherche Archéologie et Architecture. Nantes: 491-567.

Cassen S., Lanos P., Dufresne P., Oberlin C., Delqué-Kolic E., and Le Goffic M. 2009. Datations sur site (Table des Marchands, alignement du Grand Menhir, Er Grah) et modélisation chronologique du Néolithique morbihannais. In S. Cassen (ed.), Autour de la Table. Explorations archéologiques et discours savants sur une architecture néolithique restaurée à Locmariaquer, Morbihan (Table des Marchands et Grand Menhir). Actes du colloque international, Vannes (Morbihan), 5-7 octobre 2007 (Université de Bretagne-Sud, campus Le Tohannic). Université de Nantes, Laboratoire de recherche Archéologie et Architecture. Nantes: 737-768.

Cassen S., Pétrequin P., Boujot C., Dominguez Bella S., Guiavarc'h M., and Querré G. 2011. Measuring distinction inside the architectures of the Carnac region. From sign to material. In M. Furholt, F. Lüth, and J. Muller (eds.), Megaliths and Identities. Frühe Monumentalität und soziale Differenzierung 1. Schwerpunktprogramm 1400. European Megalithic Studies Group Meeting, $13^{\text {th }}$ to $15^{\text {th }}$ of May 2010 in Kiel (Germany). Dr. Rudolf Habelt GmbH. Bonn: 225-248. https://doi.org/10.12766/jna.2010.45 
Cassen S., Boujot C., Dominguez Bella S., Guiavarc'h M., Le Pennec C., Prieto Martinez M. P., Querré G., Santrot M. H., and Vigier E. 2012. Dépôts bretons, tumulus carnacéens et circulations à longue distance. In P. Pétrequin, S. Cassen, M. Errera, L. Klassen, A. Sheridan, and A. M. Pétrequin (eds.), Jade. Grandes haches alpines du Néolithique européen. Ve et IVe millénaires av. J.-C. Presses Universitaires de Franche-Comté (Collection Les cahiers de la MSHE Ledoux), Tome 2. Besançon: 918-994.

Cassen S., Lescop L., Grimaud V., Alvim P., and de Jersey P. 2015. Sites de passage (3). La représentation de l'arc au cours du Ve millénaire d'après les stèles de Bretagne, des îles Anglo-Normandes et de l'Alentejo. In L. Rocha, P. Bueno-Ramirez, and G. Branco (eds.), Death as Archaeology of Transition: Thoughts and Materials. IInd International Meeting on Archaeology of Transition. The Funerary World, Evvora University (Portugal), April 29th to May 1st, 2013. British Archaeological Reports IS 2708. Archaeopress. Oxford: 95-125.

Cassen S., Chaigneau C., Grimaud V., Lescop L., Rousset J. M., and Vigier E. 2016. Le déplacement des mégalithes extraordinaires sur le littoral morbihannais. Modèles d'embarcations et questions relatives à la navigation atlantique dès le Ve millénaire av. J.-C. In M. Acerra, C. Cerino (ed.), IIe Congrès du GIS d'histoire maritime. Nantes 2628 juin 2013, La maritimisation du monde de la préhistoire à nos jours. Presses de l'université de Paris-Sorbonne. Paris: 235-302.

Cassen S., Grimaud V., Lescop L. Paitier H., Rodríguez-Rellán C., and Vinçotte A. 2017. The "historiated" Neolithic stela of Saint-Samson-sur-Rance (Côtes-d'Armor, France). Cambridge Archaeological Journal 28(2): 259-281. https://doi.org/10.1017/S0959774317000853

Cassen S., Grimaud V., and Paitier H. 2018. Les monolithes gravés dans la tombe à couloir néolithique du Mané er Groez à Kercado (Carnac, Morbihan). Gallia Préhistoire 58: 87-138. https://doi.org/10.4000/galliap.795

Cassen S., Charvet A., Grimaud V., Le Maux N., Le Pennec C., Querré G., Vigier E., Obeltz C., Prodéo F., and Villes A. 2019. La parure en callaiis (variscite et turquoise), au Néolithique, dans la moitié nord de la France. Corpus et contextes. In G. Querré, S. Cassen, and E. Vigier (eds.), Callaï - La parure en callaïs (variscite, turquoise) du Néolithique européen. Carnac 1-2 avril 2015. Archaeopress. oxford: 203-279.

Childe V. G. 1932. The Continental affinities of British Neolithic pottery. Archaeological Journal 88: 37-66.

1942 [1961]. Le Mouvement de l'Histoire (What happened in History). Ed. Artaud. Paris.
Closmadeuc G. (de) 1868. Les Fouilles et les découvertes récentes de M. l'abbé Collet, vicaire de St-Pierre-Quiberon. Bulletin Société Polymatique du Morbihan: 171-175.

1873. Sculptures lapidaires et signes gravés des dolmens dans le Morbihan. Imp. De Lamarzelle. Vannes.

Caylus A. C. P., de Pestels de Lévis de Tubières-Grimoard (de) 1762-1767. Recueil d'antiquités égyptiennes, étrusques, grecques, romaines et gauloises. Chez N. M. Tilliard, Libraire, quai des Augustins. Paris.

Daniel G. E. 1941. The dual nature of the megalithic colonization of prehistoric Europe. Proceedings of the British Society 7: 1-49.

Darvill T., Bayliss A. Costen D., Hambleton E., Healy F., Housley R. A., O'Connell L., Pollard M., Snashall N., and Whittle A. 2011. Excavations at a Neolithic enclosure on The Peak, near Birdlip, Gloucestershire. Proceedings of the Prehistoric Society 77: 139-204. https://doi.org/10.1017/S0079497X00000669

Déchelette J. 1908. Manuel d'Archéologie préhistorique et celtique. 1 - Archéologie préhistorique. Lib. Picard. Paris.

Domínguez-Bella S., Bóveda M. J. 2011. Variscita y ámbar en el Neolítico gallego. Análisis arqueométrico del collar del túmulo 1 de Chousa Nova, Silleda (Pontevedra, España). Trabajos de Prehistoria 68: 369-380.

https://doi.org/10.3989/tp.2011.11075

Fábregas Valcarce R., Lombera Hermida A., and Rodríguez Rellán C. 2012. Spain and Portugal: long chisels and perforated axes. Their context and distribution. In P. Pétrequin, S. Cassen, M. Errera, L. Klassen, and A. Sheridan (eds.), Jade. Grandes haches alpines du Néolithique européen. Ve et IVe millénaires av. J.-C. Presses Universitaires de Franche-Comté (Collection Les cahiers de la MSHE Ledoux), Tome 2. Presses Universitaires de Franche-Comté. Besançon. Centre de recherche archéologique de la Vallée de l'Ain. Gray, Besançon: 1108-1135.

Forde C. D. 1930. Early Cultures of Atlantic Europe. American Anthropologist 32(1): 19-10.

Garrow D., Sturt F. 2011. Grey waters bright with Neolithic argonauts? Maritime connections and the MesolithicNeolithic transition within the 'western seaways' of Britain, c. 5000-3500 BC. Antiquity 85: 59-72. https://doi.org/10.1017/S0003598X00067430

Gimbutas M. 1989. The Language of the Goddess. Thames \& Hudson. London.

Giot P.-R. 1987. Barnenez, Carn, Guennoc. Travaux du Laboratoire d'Anthropologie Préhistoire. Université de Rennes I. Rennes. 
Gomes M. V. 1994. Menires e cromeleques no complexo cultural magalitico português. Trabalhos recentes e estado da questão. Actas do seminario 0 Megalitismo no centro do Portugal (Mangualde, 1992). Estudos Prehistoricos II: 317-342.

1997. Estatuas-menhires antropomorficas do alto-Alentejo. Descorbertas recentes e problematica. In A. Rodriguez Cazal (ed.), IIe Colloquio Intern. de Arte megalitico, A Coruña, 1997. Brigantium 10: 255-279.

2010. Time and Signs. Southern Portugal megalithic art diachrony. In D. Calado, M. Baldia, and M. Boulanger (eds.), Monumental questions: prehistoric megaliths, mounds and enclosures. 15th UISPP Congress, Lisboa (Portugal), session C68- abstracts. British Archaeological Reports IS 2122. Archaeopress. Oxford: 17-24.

2011. 0 alinhamento da Vilarinha (São Bartolomeu de Messines, Silves). In Arquitectura e arte megalitica. Actas do $5^{\circ}$ Encontro de Arqueologia do Algarve, XELB 8: 75-102.

Gonçalves V. S. 1999. Reguengos de Monsaraz territorios megaliticos. Câmara Municipal de Reguengos de Monsaraz. Lisboa.

Guérin T. W. M. (de) 1920. Notes on the recent discovery of a human figure sculptured on a capstone of the dolmen of Déhus. Guernsey Society of natural science and local research. Report and transactions 1919: 213-221.

Hugo V. 1816-1883. Océan: Tas de pierres. Ed. A. Michel, 1942. La Librairie Ollendorf. Paris.

Lavenot (Abbé) 1888. Les Îles d'Hoëdic et Houat et la presqu'île de Quiberon. Bulletin Société Polymatique du Morbihan 38: 171-175.

Le Guern C. 2011. Quelques haches polies et un galet aménagé découverts dans le Finistère. Bulletin de la société d'archéologie et d'histoire du pays de Lorient 39 (2010-2011): 57-59.

Le Roux C.-T. 1997. Et voguent les menhirs? Bulletin de Association Manche Atlantique pour la Recherche Archéologique dans les îles 10: 5-18.

Le Roux C. T., Lecerf Y. 2003. Le Grand cairn de Barnenez, mausolée néolithique. Monum, Editions du Patrimoine. Paris.

L'Helgouac'h J. 1971. Les débuts du Néolithique en Armorique au $4 \mathrm{e}$ millénaire et son développement au commencement du $3^{\mathrm{e}}$ millénaire. In J. Lüning (ed.), Die Anfänge des Neolithikums von Orient bis Nordeurope. Fundamenta A3.VI. Böhlau. Köln: 178-201.
1991. Déesses et figurations cornues du Néolithique. In H. de Lumley, A. Lautman (eds.), Le Mont Bego, Une montagne sacrée de l'Age du Bronze. Institut de paléontologie humaine. Paris: 537-557.

Mañana Borrazás M. 2005. Túmulo 5 de Forno dos Mouros (Ortigueira, A Coruña). Primeiros resultados. Cuadernos de estudios gallegos 52(118): 39-79.

https://doi.org/10.3989/ceg.2005.v52.i118.91

Mohen J. P. 2009. Pierres vives de la Préhistoire. Dolmens et menhirs. Ed. Odile Jacob. Paris.

Mortillet A. 1894. Les figures sculptées sur les monuments mégalithiques de France. Revue École d'Anthropologie de Paris: 273-307.

Péquignot B. 2006. De l'usage des images en sciences sociales. Communications 80: 41-51.

Pétrequin P., Cassen S, Gauthier E., Klassen L., Pailler Y., and Sheridan A. 2012a. Typologie, chronologie et répartition des grandes haches alpines en Europe occidentale. In P. Pétrequin, S. Cassen, M. Errera, L. Klassen, A. Sheridan, and A. M. Pétrequin (eds.), Jade. Grandes haches alpines du Néolithique européen. Ve et IVe millénaires av. J.-C. Presses Universitaires de Franche-Comté et Centre de recherche archéologique de la Vallée de l'Ain (Collection Les cahiers de la MSHE Ledoux). Besançon: 574-727.

Pétrequin P., Cassen S, Klassen L., and Fábregas Valcarce R. 2012b. La circulation des haches carnacéennes en Europe occidentale. In P. Pétrequin, S. Cassen, M. Errera, L. Klassen, A. Sheridan, and A. M. Pétrequin (eds.), Jade. Grandes haches alpines du Néolithique européen. Ve et IVe millénaires av. J.-C. Presses Universitaires de FrancheComté et Centre de recherche archéologique de la Vallée de l'Ain (Collection Les cahiers de la MSHE Ledoux). Besançon: 1015-1045.

Pétrequin P., Cassen S., Errera E., Klassen L., Tsonev T., Dimitrov K., and Mitkova R. 2012c. Les haches en "jades alpins« en Bulgarie. In P. Pétrequin, S. Cassen, M. Errera, L. Klassen, A. Sheridan, and A. M. Pétrequin (eds.), Jade. Grandes haches alpines du Néolithique européen. Ve et IVe millénaires av. J.-C. Presses Universitaires de Franche-Comté et Centre de recherche archéologique de la Vallée de l'Ain (Collection Les cahiers de la MSHE Ledoux). Besançon: 1231-1279.

Pétrequin P., Cassen S., Chevillot C., Errera M., Pailler Y., Pétrequin A. M., Prichytal A., and Prodéo F. 2015. La production des anneaux-disques alpins pendant les VIe et Ve millénaires av. J.-C. et le Mont Viso. In A. Dumont, P.-J. Rey (eds.), L'homme et son environnemen: des lacs, des montagnes et des rivières. Bulles d'archéologie offertes à André Marguet, (suppl. RAE 40): 259-302. 
Philippe M. 2018. Un état des connaissances sur la navigation préhistorique en Europe atlantique. Bulletin de la Société préhistorique française 115(3): 567-597.

Piggott S. 1953. Les Relations entre l'ouest de la France et les îles britanniques dans la Préhistoire. Annales $d u$ Midi 65(21): 5-20

Plumet P. 2004. Des mythes à la Préhistoire. Peuple du Grand Nord. Tome 1. Editions Errance. Paris.

Procope de Césarée. Procopius De bello gottorum. Bibliothèque nationale de France (1995). Paris.

Querré G., Pioline N., and Le Roux C. T. 2006. La Géologie du socle et ses implications. In C. T. Le Roux (ed.), Monuments mégalithiques à Locmariaquer (Morbihan). Le long tumulus d'Er-Grah dans son environnement. 38e Supplément à Gallia Préhistoire. Edition de Centre national de la recherche scientifique. Paris: 25-29.

Querré G., Herbault F., and Calligaro T. 2008. Transport of Neolithic variscites demonstrated by PIXE analysis. $X$ Ray Spectrom 37: 116-120.

https://doi.org/10.1002/xrs.1031

Querré G., Calligaro T., and Cassen S. 2019. Origine des bijoux néolithiques en Callaïs de l'ouest de la France. In G. Querré, S. Cassen, and E. Vigier (ed.), Callaïs - La parure en callaïs (variscite, turquoise) du Néolithique européen. Carnac 1-2 avril 2015. Archaeopress. Oxford: 129-198.

Sergent B. 2011. Pierres, miracles et géants des Côtes d'Armor de Morlaix à Guingamp. In Guide de la France merveilleuse. Bretagne, Pays de Loire, Normandie, Picardie. Ed. Payot, Société de mythologie française. Paris: $35-50$.

Schulz Paulsson B., Cassen S., Rodríguez Rellán C., Faustino Carvalho A., Vaquer J., Molist Montaña M., Bosch Argilagós J., and Oliva Poveda M. 2019. The time of the callaiis: radiocarbon dates and Bayesian chronological modelling. In G. Querré, S. Cassen, and E. Vigier (eds.), Callaïs - La parure en callaïs (variscite, turquoise) du Néolithique européen. Carnac 1-2 avril 2015. Archaeopress. 0xford: 479-507.

Shee Twohig E. 1981. The Megalithic Art of western Europe. Clarendon Press. Oxford.

Sheridan A., Pailler Y. 2011. La néolithisation de la Grande-Bretagne et de L'Irlande: plusieurs processus, plusieurs modèles et des questions à l'attention de nos collègues français. Revue Archéologique de Picardie 28: 13-30.

Siret L. 1920. La Dame de l'érable. L'Anthropologie 30: 226-321.

Strabon [1986]. Géographie, IV, 6. trad. Edm. Cougny. Ed. Errance. Paris.

Suárez Otero J. 1997. El yacimiento de A Cunchosa y el Neolítico en Galicia. Primera aproximación al contexto cultural de la aparición del Megalitismo en Galicia. In A. Rodríguez Casal (ed.), O neolítico atlántico e as orixes do megalitismo. Actas do Coloquio Internacional, Santiago de Compostela, 1-6 de abril de 1996. Universidade de Santiago de Compostela. Servizo de Publicacións e Intercambio Cientifico. Santiago de Compostela: 485-506.

Tacite. Euvres complètes (traduction de Pierre Grimal). Ed. Gallimard (coll. Pléiade), 1990. Paris.

Vaquero Lastres J. 1999. Les extrêmes distincts. La configuration de l'espace dans les societés ayant batî des tertres funéraires dans le Nord-Ouest iberíque. British Archaeological Reports IS 821. Archaeopress. Oxford.

Whittle A. W. R. 2000. Very like a whale: menhirs, motifs and myths in the Mesolithic-Neolithic transition of northwest Europe. Cambridge Archaeological Journal 10(2): 243-259. https://doi.org/10.1017/S0959774300000093

\section{back to contents}

